\title{
sciendo
}

\section{SELECTED PHYSICAL AND CHEMICAL CHARACTERISTICS OF EGGS LAID BY HENS FED DIETS WITH DIFFERENT LEVELS OF HYBRID RYE*}

\author{
Ewelina Węsierska ${ }^{1 \bullet}$, Katarzyna Niemczyńska ${ }^{1}$, Małgorzata Pasternak $^{1}$, Anna Arczewska-Włosek $^{2}$
}

\author{
${ }^{1}$ Department of Animal Product Technology, University of Agriculture in Kraków, \\ Balicka 122, 30-149 Kraków, Poland \\ ${ }^{2}$ National Research Institute of Animal Production, 32-083 Balice n. Kraków, Poland \\ •Corresponding author: ewelina.wesierska@urk.edu.pl
}

\begin{abstract}
The aim of the study was to evaluate the effect of different levels of dietary hybrid rye on eggs laid by Isa Brown laying hens and their quality, such as physical parameters, nutritional value (basic chemical composition, cholesterol content, fatty acid profile) as well as safety (microbiological purity). A total of 72 Isa Brown hens aged 26 weeks were allocated to 3 groups fed with $0 \%, 15 \%$ and $\mathbf{2 5 \%}$ levels of hybrid rye in their diet up to week 50. At week 50, 72 eggs per group were collected for analysis. The $\mathbf{2 5 \%}$ rye level had no significant effect on most of the examined physical parameters; however, a tendency to heavier eggs in this group was noted. An increased rye level resulted in lighter yolks with a lowered share of redness and yellowness compared to those obtained from hens fed a control diet. The administration of $25 \%$ of rye in the diet influenced the basic chemical composition of the yolks by increasing the water content and reducing the fat content, but with no significant effect on the contents of ash, chlorides and cholesterol. The sum of saturated fatty acids in yolks decreased along with the increase in dietary rye level while the sum of mono- and polyunsaturated fatty acids increased. Moreover, a lowered ratio of $\omega-6: \omega-3$ fatty acids was found with dietary rye level increases.
\end{abstract}

Key words: rye grains, egg quality, fatty acid profile

Rye has been repeatedly tested for its utility in the production of feed for chickens and hens (Lumpkins and Batal, 2005; Lumpkins et al., 2005; Kowieska et al., 2011). The digestibility of nutrients, the content of metabolisable energy, the balance of nitrogen, calcium, phosphorus and zinc as well as digesta viscosity have been analysed. The results of research have indicated that the addition of rye to laying hen feed in the amount of $10-20 \%$ is acceptable and does not have a negative impact on

*This study was supported by the "ENERGYFEED" grant, contract number BIOSTRATEG/297910/12/NCBR/2016, financed by the National Centre for Research and Development, Poland. 
its digestibility. Due to the presence of non-starch polysaccharides (NSP) and arabinoxylans, a higher rye content decreases the nutritional value of feed, although it positively affects the balance of phosphorus in laying hens. The addition of enzymes hydrolysing NSP is one of several ways to reduce their negative impact on the digestibility of nutrients (Świątkiewicz and Koreleski, 2007; Schwarz et al., 2015). Due to the addition of exogenous enzymes, the rye content in laying hen diets may be higher $(10-40 \%)$ than in those for broiler chickens (10-20\%), as the risk of an adverse impact on performance indicators is lower (Smulikowska and Rutkowski, 2005). Another method is to use new varieties of hybrid rye, characterised by higher yield, resistance to fungi and pests, low production costs and a significantly lower content of anti-nutritive substances (Bederska-Łojewska et al., 2017). Due to its valuable chemical composition and health-promoting properties, rye, along with wheat, is a valuable raw material for food production (Jasińska et al., 2006; Björk et al., 2012; Gani et al., 2012). Despite the lower content of protein, fat and crude fibre compared to barley and wheat, rye contains high amounts of linoleic acid and is rich in lysine, which compensates for the lower protein content and increases the nutritional value (Kowieska et al., 2011). The differences in protein content between cereal species presented in Table 1 are not large and can fluctuate depending on the cultivation systems (Boroś and Fraś, 2015).

Table 1. The basic composition of the grains of selected cereals (Boroś and Fraś, 2015)

\begin{tabular}{l|c|c|c|c}
\hline \multicolumn{1}{c|}{ Grain } & Total protein (\%) & Raw fat (\%) & Crude fibre (\%) & Starch (\%) \\
\hline Barley & 11.0 & 2.1 & 4.8 & 52.3 \\
Wheat & 11.9 & 2.0 & 2.9 & 59.4 \\
Maize & 9.0 & 4.0 & 2.3 & 61.4 \\
Rye & 9.5 & 1.6 & 2.4 & 54.5 \\
Triticale & 12.2 & 1.4 & 2.4 & 56.5 \\
Oat & 11.8 & 4.1 & 8.9 & 39.3 \\
\hline
\end{tabular}

Rye grain is rich in vitamins, phenolic acids and phytoestrogens. Of all cereals, rye has the lowest (net) calorific value. There is a need, therefore, to assess the nutritional value of new rye hybrids, in terms of both the health of the laying hens and the nutritional quality of the eggs (Jasińska et al., 2006). The aim of the study was to determine the effect of increasing (different) levels of dietary hybrid rye on the physical parameters and nutritional value (basic chemical composition, cholesterol content, fatty acid profile) of eggs laid by Isa Brown laying hens.

\section{Material and methods}

The experimental materials were eggs obtained from 50-wk-old hens fed diets with different levels of hybrid rye. A total of 72 17-wk-old Isa Brown hens were obtained from a commercial source and kept in cages with wire-mesh floors, 2 hens per cage. During the pre-experimental period (18-25 wks of age) hens were fed a standard, commercial diet and kept under controlled climate conditions. At wk 26, the hens 
were separated into 3 experimental Groups (I, II or III), with 12 repetitions (cages with 2 birds in each) and fed isocaloric and isoprotein experimental diets with different hybrid rye levels: $0 \%, 15 \%$ or $25 \%$, respectively, until wk 50 (Table 2 ).

Table 2. Composition of the experimental diets

\begin{tabular}{l|c|c|c}
\hline \multicolumn{1}{c|}{ Component (g/kg) } & $\begin{array}{c}\text { Group I } \\
\text { (Rye 0\%) }\end{array}$ & $\begin{array}{c}\text { Group II } \\
(\text { Rye 15\%) }\end{array}$ & $\begin{array}{c}\text { Group III } \\
\text { (Rye 25\%) }\end{array}$ \\
\hline Rye & 0.0 & 150 & 250 \\
Corn & 290 & 200 & 150 \\
Wheat & 382.3 & 311.6 & 250.8 \\
Soybean meal & 200 & 205 & 210 \\
Rapeseed oil & 15 & 21 & 27 \\
Limestone & 91 & 91 & 91 \\
Monocalcium phosphate & 12 & 12 & 12 \\
NaCl & 3 & 3 & 3 \\
DL-Methionine & 1.1 & 1.1 & 1.1 \\
L-Lysine HCl & 0.6 & 0.3 & 0.1 \\
Vitamin-mineral premix ${ }^{1}$ & 5 & 5 & 5
\end{tabular}

Calculated nutritional value per kg of feed

$\begin{array}{lc}\text { Metabolisable energy }(\mathrm{MJ} / \mathrm{kg})^{2} & 11.55 \\ \text { Crude protein }(\mathrm{g} / \mathrm{kg} \mathrm{DM}) & 170 \\ \text { Lys }(\mathrm{g} / \mathrm{kg} \mathrm{DM}) & 8.10 \\ \text { Met }(\mathrm{g} / \mathrm{kg} \mathrm{DM}) & 3.60 \\ \text { Ca }(\mathrm{g} / \mathrm{kg} \mathrm{DM}) & 36 \\ \text { Available P }(\mathrm{g} / \mathrm{kg} \mathrm{DM}) & 3.75\end{array}$

${ }^{1}$ The premix provided, per kg of diet: retinyl acetate 10,000 IU; cholecalciferol, 2,000 IU; tocopheryl, $20 \mathrm{IU}$; menadione sodium bisulfite, $1.5 \mathrm{mg}$; thiamine, $1 \mathrm{mg}$; riboflavin, $4 \mathrm{mg}$; pyridoxine, $1.5 \mathrm{mg}$; cyanocobalamin, 0.01 $\mathrm{mg}$; Ca-pantothenate, $8.7 \mathrm{mg}$; niacin, $20 \mathrm{mg}$; folic acid, $0.85 \mathrm{mg}$; choline chloride, $200 \mathrm{mg}$; manganese, $85 \mathrm{mg}$; zinc, $60 \mathrm{mg}$; iron, $45 \mathrm{mg}$; copper, $8 \mathrm{mg}$; iodine, $1 \mathrm{mg}$; selenium, $0.25 \mathrm{mg}$.

${ }^{2}$ Calculated according to European Table (Janssen, 1989) as the sum of the ME content of components.

The hybrid rye used in the study was Brasetto variety, developed by KWS Lochow GmbH, Bergen, Germany. During the experimental period (26-50 wks of age) the hens were kept in cages, with free access to feed and water, with standard housing conditions and were exposed to a 14 L:10 D lighting schedule. At 50 wks of age, eggs were collected in each cage, from each hen, on three consecutive days. A total of 216 eggs were tested ( 72 eggs from each group). The result was the average of 6 eggs ( 2 eggs per cage $\times 3$ collection days). The analysis of internal egg characteristics included the following parameters: egg weight, white mass, yolk mass, eggshell mass, egg index (Radwag laboratory scale, micrometre Mitutoyo 500-181-30; PN-A-86503:1998), yolk colour CIE L*a*b* (Minolta CR200b analyser calibrated according to the white reference standard: $\mathrm{L}^{*}=94.2 ; \mathrm{a}^{*}=0.3133 ; \mathrm{b}^{*}=0.320 ;$ Wyszecki and Stiles, 1982), saturation $\left(\sqrt{ } \mathrm{a}^{*} 2+\mathrm{b}^{*} 2\right)$, hue $\left(\operatorname{arctg} \mathrm{b}^{*} / \mathrm{a}^{*}\right)$, depth of the air chamber (ovolux lamp; PN-A-86503:1998), and yolk index (Mitutoyo digital altimeter $0-300 / 0.01 ; \mathrm{h} / \mathrm{dx} 100 \%$, where: $\mathrm{h}$ is the height of yolk in $\mathrm{mm}, \mathrm{d}$ is the diameter of yolk in $\mathrm{mm}$ ). The assessment of the basic chemical composition of white and yolk included: water and ash content by drying samples to stable weight (PN-ISO-1442:2000), protein content by the Kjeldahl method (PN-A-04018:1975/Az 3:2002) with set type 
322 (Büchi), fat content by the Soxlet method (ISO-1444:2000), chlorides content by the Mohr method (PN-A-82112:1973/Az1:2002). Determination of cholesterol content was carried out by gas chromatography (SOP M.023, issue 1, 15/04/2011) in yolk samples (Russo et al., 2005). The fatty acid profile was determined by gas chromatography from the fat extracted from the yolk samples (Folch et al., 1957). A Trace GC Ultra (Thermo Electron Corporation) with a Supelcowax 10 column (Supelcowax, Bellefonte, USA) $30 \mathrm{~m} \times 0.25 \mathrm{~mm} \times 0.25 \mu \mathrm{m}$ was used for the determination. The analysis was carried out under the following conditions: helium carrier gas $1 \mathrm{ml} / \mathrm{min}$, split flow $10 \mathrm{ml} / \mathrm{min}$, injector temperature $220^{\circ} \mathrm{C}$, detector temperature $250^{\circ} \mathrm{C}$, starting temperature of the column (first $3 \mathrm{~min}$ ) $160^{\circ} \mathrm{C}$, increased by $3^{\circ} \mathrm{C} /$ min to $210^{\circ} \mathrm{C}$ and maintained for $25 \mathrm{~min}$. The effect of dietary rye level $(0 \%, 15 \%$, $25 \%$ ) on the physicochemical, chemical and microflora composition parameters of eggs was tested using one-way analysis of variance (ANOVA). Duncan post-hoc tests were used for the comparison of means (the significance of differences was investigated at $\mathrm{P} \leq 0.05)$.

\section{Results}

As presented in our previous paper (Bederska-Łojewska et al., 2019), the increasing level of rye grain in the diet did not negatively affect laying performance indices (egg production, feed conversion ratio) in this study. The effect of the rye level in the diet of laying hens on the physical characteristics of hens eggs is shown in Table 3 . The weight of eggs, as well as the egg index were not significantly affected by an increasing dietary rye level; however, there was a tendency for an increase in egg weight along with higher dietary rye level. The administration of $25 \%$ of rye in the diet resulted in an increase in white weight and a decrease in yolk and eggshell weights, when compared with results obtained in the group of hens fed with a $15 \%$ rye diet. These results were not significantly different than those obtained in the control group.

Table 3. One-way analysis of the variance of the physical parameters of eggs of laying hens fed with $0 \%, 15 \%$ and $25 \%$ dietary rye levels

\begin{tabular}{l|c|c|c|c|c|c}
\hline \multirow{2}{*}{\multicolumn{1}{c|}{ Physical parameters }} & \multicolumn{2}{c|}{ Group I } & \multicolumn{2}{c|}{ Group II } & \multicolumn{2}{c}{ Group III } \\
\cline { 2 - 7 } & mean & SD & mean & SD & mean & SD \\
\hline White weight (\%) & $56.15 \mathrm{ab}$ & 2.16 & $55.10 \mathrm{a}$ & 2.46 & $56.44 \mathrm{~b}$ & 4.4 \\
Yolk weight (\%) & $29.25 \mathrm{a}$ & 2.49 & $30.49 \mathrm{~b}$ & 2.95 & $28.87 \mathrm{a}$ & 3.1 \\
Shell weight (\%) & $14.12 \mathrm{ab}$ & 1.83 & $14.10 \mathrm{a}$ & 1.47 & $13.54 \mathrm{~b}$ & 1.3 \\
Egg index (\%) & 77.2 & 3.82 & 76.5 & 2.5 & 76.7 & 2.7 \\
\hline
\end{tabular}

$\mathrm{a}, \mathrm{b}$ - Different letters in a row indicate statistically significant differences at $\mathrm{P} \leq 0.05 ; \mathrm{SD}$ - standard deviation; $\mathrm{n}=12$.

The analysis of the colour parameters of egg yolks is presented in Table 4. The results for parameters $\mathrm{a}^{*}$ and $\mathrm{b}^{*}$ on the CIE L*a*b* scale showed a significant decrease in the share of red and yellow colours in the yolks of layers fed with an in- 
creasing level of dietary rye $(\mathrm{P} \leq 0.05)$, respectively from 8.0 and 49.0 (Group I) to 4.3 and 39.2 (Group III). An increase in the level of rye in the diets resulted in an increase in the $\mathrm{L}^{*}$ parameter, specifying the lightness of yolks $(\mathrm{P} \leq 0.05)$, from 63.8 (Group I) to 65.9 (Group II) and 65.7 (Group III), along with a reduction in colour saturation, respectively from 49.6 to 43.8 and $39.4(\mathrm{P} \leq 0.05)$. The yolk of the studied groups did not differ significantly in terms of its colour shade, which was determined by the value of 1.4 .

Table 4. Colour parameters of egg yolks of laying hens fed with $0 \%, 15 \%$ and $25 \%$ dietary rye levels

\begin{tabular}{l|c|c|c|c|r|r}
\hline \multirow{2}{*}{ Colour parameters } & \multicolumn{2}{|c|}{ Group I } & \multicolumn{2}{c|}{ Group II } & \multicolumn{2}{c}{ Group III } \\
\cline { 2 - 7 } & mean & SD & mean & SD & mean & SD \\
\hline L* & $63.8 \mathrm{a}$ & 1.9 & $65.9 \mathrm{~b}$ & 2.1 & $65.7 \mathrm{~b}$ & 2.3 \\
$\mathrm{a}^{*}$ & $8.0 \mathrm{a}$ & 0.9 & $5.3 \mathrm{~b}$ & 0.7 & $4.3 \mathrm{c}$ & 0.6 \\
$\mathrm{~b}^{*}$ & $49.0 \mathrm{a}$ & 1.8 & $43.5 \mathrm{~b}$ & 1.5 & $39.2 \mathrm{c}$ & 1.4 \\
Saturation & $49.6 \mathrm{a}$ & 1.9 & $43.8 \mathrm{~b}$ & 1.5 & $39.4 \mathrm{c}$ & 1.5 \\
Hue & 1.4 & 0.1 & 1.4 & 0.1 & 1.4 & 0.2 \\
\hline
\end{tabular}

a, b, c - Different letters in a row indicate statistically significant differences at $\mathrm{P} \leq 0.05 ; \mathrm{SD}$ - standard deviation; $\mathrm{n}=12$.

The basic chemical composition of yolks is presented in Table 5. Both levels of dietary rye resulted in a higher water content and lower fat content in yolks, in comparison to the control group. These values were similar for both groups receiving rye in their diet $(\mathrm{P} \leq 0.05)$. The lowest protein and cholesterol contents were found in yolks of hens receiving the $15 \%$ rye diet, while those parameters obtained in the group of hens receiving the $25 \%$ rye diet did not differ from those for the control group. The egg yolk of all the studied groups did not differ in terms of the content of ash and chlorides, which were determined at about $1.5 \%$ and $0.3 \%$, respectively.

Table 5. Basic chemical composition and cholesterol content of egg yolks of laying hens fed with $0 \%$, $15 \%$ and $25 \%$ dietary rye levels

\begin{tabular}{l|c|c|c|c|c|c}
\hline \multirow{2}{*}{ Chemical composition } & \multicolumn{2}{|c|}{ Group I } & \multicolumn{2}{c|}{ Group II } & \multicolumn{2}{c}{ Group III } \\
\cline { 2 - 7 } & mean & SD & mean & SD & mean & SD \\
\hline Water content (\%) & $53.4 \mathrm{a}$ & 0.8 & $55.5 \mathrm{~b}$ & 1.1 & $54.7 \mathrm{~b}$ & 1.0 \\
Protein content (\%) & $16.7 \mathrm{a}$ & 1.3 & $16.1 \mathrm{~b}$ & 0.6 & $16.5 \mathrm{a}$ & 0.6 \\
Fat content (\%) & $29.4 \mathrm{a}$ & 1.3 & $26.8 \mathrm{~b}$ & 0.7 & $26.4 \mathrm{~b}$ & 2.9 \\
Ash content (\%) & 1.5 & 1.0 & 1.5 & 3.6 & 1.5 & 0.2 \\
Chloride content (\%) & 0.3 & 0.1 & 0.3 & 0.1 & 0.3 & 0.1 \\
Cholesterol content (mg/g) & $11.0 \mathrm{a}$ & 0.2 & $10.6 \mathrm{~b}$ & 0.1 & $11.0 \mathrm{a}$ & 0.1 \\
\hline
\end{tabular}

$\mathrm{a}, \mathrm{b}-$ Different letters in a row indicate statistically significant differences at $\mathrm{P} \leq 0.05$; $\mathrm{SD}$ - standard deviation; $\mathrm{n}=12$.

The proportion of fatty acids in the profile is presented as a percentage and is compared in Table 6 for saturated fatty acids (SFA) and Table 7 for mono- (MUFA) and polyunsaturated (PUFA) fatty acids. 
Table 6. Saturated fatty acids in egg yolks of laying hens fed with $0 \%, 15 \%$ and $25 \%$ dietary rye levels

\begin{tabular}{l|c|c|c|c|c|c}
\hline \multirow{2}{*}{ Systematic name } & \multicolumn{2}{c|}{ Group I } & \multicolumn{2}{c|}{ Group II } & \multicolumn{2}{c}{ Group III } \\
\cline { 2 - 7 } & mean & SD & mean & SD & mean & SD \\
\hline decanoic C10:0 & 0.01 & 0.01 & 0.01 & 0.01 & 0.01 & 0.01 \\
dodecanoic C12:0 & 0.01 & 0.01 & 0.01 & 0.01 & 0.01 & 0.01 \\
tetradecanoic C14:0 & $0.18 \mathrm{a}$ & 0.04 & $0.16 \mathrm{ab}$ & 0.02 & $0.14 \mathrm{~b}$ & 0.02 \\
pentadecanoic C15:0 & $0.03 \mathrm{a}$ & 0.01 & $0.02 \mathrm{~b}$ & 0.01 & $0.02 \mathrm{~b}$ & 0.01 \\
hexadecanoic C16:0 & 28.50 & 0.59 & 26.55 & 3.58 & 25.01 & 0.18 \\
heptadecanoic C17:0 & $0.08 \mathrm{a}$ & 0.02 & $0.07 \mathrm{ab}$ & 0.01 & $0.06 \mathrm{~b}$ & 0.01 \\
octadecanoic C18:0 & 6.64 & 0.64 & 6.45 & 1.02 & 5.92 & 0.55 \\
eicosanoic C20:0 & 0.01 & 0.01 & 0.01 & 0.01 & 0.01 & 0.01 \\
$\Sigma$ & 35.44 & & 33.21 & & 31.18 & \\
\hline
\end{tabular}

$\mathrm{a}, \mathrm{b}-$ Different letters in a row indicate statistically significant differences at $\mathrm{P} \leq 0.05$; $\mathrm{SD}$ - standard deviation; $\mathrm{n}=12$.

The predominant SFAs in the analysed yolks were palmitic (C:16) and stearic $(\mathrm{C}: 18)$, and a tendency $(\mathrm{P} \leq 0.05)$ for the highest amounts of these was determined in Group I (28.5 and 6.6\%, respectively), then in Groups II (26.5 and 6.4\%) and III (25.0 and $5.9 \%)$. The $25 \%$ level of rye and the consequent higher level of rapeseed oil in the diet resulted in a decreased amount of SFA, especially myristic (from 0.18 to $0.14 \%$ ), pentadecanoic (from 0.03 to $0.02 \%$ ), and margaric (from 0.08 to $0.06 \%$ ). The sum of SFAs decreased along with the increase in dietary rye level and amounted to $35.4,33.2$ or $31.2 \%$, respectively, in Groups I, II, and III. The dominant monounsaturated acids in Group I-III yolks were oleic (C18:1 n-9) and palmitooleic (C16:1 n-7) at 42.2-46.9\% and 3.9-4.0\%, respectively. The yolks of eggs obtained from laying hens fed a $25 \%$ rye diet were characterised by a higher share of acids palmitooleic (from 1.06 to $1.2 \%$ ), oleic (from 42.2 to $46.9 \%$ ) and vaccenic (from 3.7 to $4.2 \%$ ) - in comparison with the control group.

The sum of MUFA increased along with the dietary rye level. In the $\omega-3$ fatty acid group, along with the increase in dietary rye level, a significant increase in the levels of docosapentaenoic (from 0.03 to $0.05 \%$ ) and docosahexaenoic (from 0.43 to $0.61 \%$ ) acids was observed, while a significant increase in $\alpha$-linolenic acid content (from 0.34 to $0.43 \%$ ) was recorded only in groups of hens receiving the $25 \%$ rye diet. These changes resulted in an increase in the share of $\omega-3$ acids in egg yolks of hens fed with rye from 0.9 to $1.2 \%$. In contrast, in the $\omega-6$ fatty acid group, there was a significant reduction in the levels of linoleic (from 11.33 to $10.12 \%$ ), $\gamma$-linolenic (from 0.06 to $0.04 \%$ ), adrenic (from 0.05 to $0.04 \%$ ), and osbond acids (from 0.13 to $0.08 \%$ ) and a statistically insignificant reduction in arachidonic acid (from 0.98 to $0.86 \%$ ) and this resulted in a reduction - from 12.6 to $11.2 \%$ - in the proportion of $\omega-6$ acids in egg yolks of laying hens fed with rye. These changes influenced the $\omega-6: \omega-3$ ratios, which in Groups I, II and III were, respectively, 14.3:1, 11.4:1 and 9.6:1. 
Table 7. Mono- and polyunsaturated fatty acids in egg yolks of laying hens fed with $0 \%, 15 \%$ and $25 \%$ dietary rye levels

\begin{tabular}{|c|c|c|c|c|c|c|c|}
\hline \multirow{2}{*}{\multicolumn{2}{|c|}{ Systematic name }} & \multicolumn{2}{|c|}{ Group I } & \multicolumn{2}{|c|}{ Group II } & \multicolumn{2}{|c|}{ Group III } \\
\hline & & mean & SD & mean & SD & mean & SD \\
\hline 9-tetradecenoic & C14:1 n-9 & 0.04 & 0.01 & 0.04 & 0.01 & 0.03 & 0.01 \\
\hline 9-hexadecenoic & C16:1 n-9 & $1.06 \mathrm{a}$ & 0.08 & $1.11 \mathrm{ab}$ & 0.08 & $1.16 \mathrm{~b}$ & 0.01 \\
\hline 9-hexadecanoic & C16:1 n-7 & 3.89 & 0.31 & 3.88 & 0.29 & 3.98 & 0.38 \\
\hline 9-heptadecenoic & C17:1 & 0.08 & 0.01 & 0.08 & 0.01 & 0.07 & 0.01 \\
\hline 9-octadecanoic & C18:1 n-9 & $42.22 \mathrm{a}$ & 4.94 & $45.65 \mathrm{ab}$ & 3.65 & $46.93 \mathrm{~b}$ & 0.29 \\
\hline 11-octadecanoic & C18:1 n-7 & $3.69 \mathrm{a}$ & 0.27 & $3.93 \mathrm{ab}$ & 0.32 & $4.17 \mathrm{~b}$ & 0.11 \\
\hline 9-eicosenoic & $\mathrm{C} 20: 1$ & 0.09 & 0.01 & 0.10 & 0.01 & 0.10 & 0.01 \\
\hline$\Sigma$ & & 51.04 & & 54.69 & & 56.44 & \\
\hline $9,12,15$-octadecatrienoic & $\mathrm{C} 18: 3 \mathrm{n}-3$ & $0.34 \mathrm{a}$ & 0.05 & $0.36 \mathrm{a}$ & 0.05 & $0.43 \mathrm{~b}$ & 0.16 \\
\hline 8,11,14,17-eicosatetraenoic & $\mathrm{C} 20: 4 \mathrm{n}-3$ & 0.04 & 0.01 & 0.03 & 0.01 & 0.03 & 0.01 \\
\hline $5,8,11,14,17$-eicosapentaenoic & $C 20: 5 n-3$ & 0.01 & 0.01 & 0.01 & 0.01 & 0.02 & 0.01 \\
\hline 7,10,13,16,19-docosapentaenoic & $\mathrm{C} 22: 5 \mathrm{n}-3$ & $0.03 \mathrm{a}$ & 0.01 & $0.04 \mathrm{~b}$ & 0.01 & $0.05 \mathrm{c}$ & 0.01 \\
\hline 4,7,10,13,16,19-docosahexaenoic & $\mathrm{C} 22: 6 \mathrm{n}-3$ & $0.43 \mathrm{a}$ & 0.07 & $0.50 \mathrm{~b}$ & 0.07 & $0.61 \mathrm{c}$ & 0.02 \\
\hline$\Sigma \omega-3$ & & 0.88 & & 0.97 & & 1.17 & \\
\hline 9,12-octadecadienoic & C18:2n-6 & $11.33 \mathrm{a}$ & 1.43 & $9.88 \mathrm{~b}$ & 0.69 & $10.12 b$ & 0.24 \\
\hline 6,9,12-octadecatrienoic & C18:3n-6 & $0.06 \mathrm{a}$ & 0.01 & $0.05 \mathrm{~b}$ & 0.02 & $0.04 \mathrm{~b}$ & 0.01 \\
\hline 8,11,14-eicosatrienoic & $C 20: 3 n-6$ & 0.05 & 0.00 & 0.05 & 0.01 & 0.05 & 0.00 \\
\hline 5,8,11,14-eicosatetraenoic & $\mathrm{C} 20: 4 \mathrm{n}-6$ & 0.98 & 0.16 & 0.97 & 0.11 & 0.86 & 0.04 \\
\hline $6,9,12,15$-docosatetraenoic & C22:4 n-6 & $0.05 \mathrm{a}$ & 0.01 & $0.05 \mathrm{a}$ & 0.01 & $0.04 \mathrm{~b}$ & 0.00 \\
\hline 4,7,10,13,16-docosapentaenoic & $\mathrm{C} 22: 5 \mathrm{n}-6$ & $0.13 \mathrm{a}$ & 0.02 & $0.10 \mathrm{~b}$ & 0.01 & $0.08 \mathrm{~b}$ & 0.02 \\
\hline$\Sigma \omega-6$ & & 12.60 & & 11.10 & & 11.19 & \\
\hline$\omega-6 / \omega-3$ & & $14.3: 1$ & & $11.4: 1$ & & $9.6: 1$ & \\
\hline
\end{tabular}

a,b,c - Different letters in a row indicate statistically significant differences at $\mathrm{P} \leq 0.05$; $\mathrm{SD}$ - standard deviation; $\mathrm{n}=12$.

\section{Discussion}

As rye is often a price-attractive cereal, it would be beneficial to incorporate it into the hen diets at a level higher than that usually used, $10 \%$. This would enable commercial egg production to reduce production costs, mainly by lowering feed costs, which is the dominant cost. The quality of the final product is extremely important, especially when considering the production of foodstuffs such as eggs. Thus, it is always crucial to examine the effects of nutritional modification on the properties of eggs, mainly on those connected with consumer health. While rye is still not a popular component of poultry diets, our data indicate that rye does not lead to a deterioration in the quality of eggs, even at a $25 \%$ dietary level. The egg weights were not statistically affected by rye-containing diets, similar to previous studies by Lázaro et al. (2003) or Smulikowska et al. (1997) where even higher dietary levels of rye were used, i.e. $35 \%$ or $30 \%$, respectively, when measured in hens aged 44 weeks 
or older; however, a slight numerical improvement in egg weight was noted in ryereceiving groups. Similarly, in the study by Pan et al. (1998) rye-fed hens laid bigger eggs than wheat-fed hens and this effect was statistically confirmed, although the rye was incorporated into the hens diets at the level of about $65 \%$. According to Calik (2011) and Krawczyk (2016), the mass of eggs depends not only on the age of the laying hens and their genetic predisposition (large or small eggs independent of body weight), but also on environmental factors (type of breeding and feeding). The high share of white in Group III (56.5\%) and the small egg yolk (28.7\%) confirmed the observations of Biesiada-Drzazga and Janocha (2009) as well as Lewko and Gornowicz (2016) that eggs with a higher mass are characterised by a higher share of white and a smaller share of yolk - the white content in large eggs may exceed $60 \%$ of their weight, depending on the type of feeding of the laying hens. Group II and III eggs significantly differed in the mass of white and yolk. Shells represent the highest proportion of egg weight in Group II eggs. The lower values of the Group II egg index $(76.5 \%)$ indicated a distortion in their shape along their longer axis and an increase in the susceptibility of shells to damage $(1.6 \mathrm{~kg})$, although in most measurements of physical egg quality undertaken in the present study only a little difference in measurements was noted in response to the incorporation of rye into the diet. However, there were important differences with respect to the colour parameters of egg yolks. As reported by Galobart et al. (2004), the colour of yolks according to many consumers determines the quality and suitability of culinary eggs, with yolks of orange colour being preferred. The simple ratio of yellow to red xanthophylls determines the shade of yolk. Naturally, the yellow-orange colour of yolks is obtained by feeding layers of fodder containing wheat and barley. The addition of maize or fodder containing lucerne and clover provides a greater share of red colour (Dvorak et al., 2007). In the present study, parameters $a^{*}$ and $b^{*}$ of the CIE L*a*b* scale showed a significant decrease in the redness and yellowness of the yolks along with an increasing dietary rye level $(\mathrm{P} \leq 0.05)$. The yolks of hens receiving rye were also characterised by an increase in lightness and a decrease in colour saturation. This may have been caused by a decrease in the share of maize and wheat meal in the experimental diets of layers in comparison with the control group fed with the largest share of maize and wheat meal and characterised by the highest share of red and yellow in yolks. It is worth emphasising that pale yolks in rye-receiving groups should not be a problem because usually premixes used in commercial production are fortified with pigments, while the premix used in the present experiment was free of any such pigment. The lowest water content $(53.4 \%)$ and the highest protein content $(16.7 \%)$ were determined in yolks of the control group $(\mathrm{P} \leq 0.05)$. In the remaining groups, the content of water and proteins was assessed as $54.8-55.5 \%$ and $16.1-16.5 \%$, respectively. According to Calik (2016), values above 53\% of water indicate the migration of water from protein to yolk and the beginning of ageing. The fat content in yolks decreased with an increase in the share of rye in the feed. According to Calik (2016) as well as Boroś and Fraś (2015), the chemical composition of yolk correlates with the chemical composition of feed, so the reduction of fat content in the evaluated yolks could be reduced by the share of maize and wheat cereals with a fat content of about 4 and $2 \%$, respectively, and an increasing share of rye with a fat content of 
$1.6 \%$. The lowest cholesterol content was found in the group receiving $15 \%$ rye in the diet and this was determined at $10.6 \mathrm{mg} / \mathrm{g}$. These values were lower than those published in the literature on laying eggs fed with commercial fodder: $12.0 \mathrm{mg} / \mathrm{g}$ (Siepka et al., 2015), or 13.9-15.5 mg/g (Sokołowicz et al., 2012; Calik, 2011; Cieślik and Gębusia, 2011). The decreasing content of cholesterol in yolks could be dependent on laying phase (Calik, 2016) and laying age (Sokołowicz et al., 2012). When analysing the proportion of SFA, the obtained values of the predominant palmitic and stearic acids were similar to those reported in the literature, i.e. $27.0 \%$ and $8.7 \%$ of these acids, respectively, in egg yolks of hens fed commercial feed (Grobas et al., 2001). The tendency observed in the present study to reduced stearic acid content was explained by Siepka et al. (2015) on the basis of the limited share of maize in the laying hens diet. The stearic acid content (30\%) obtained in Groups I-III was probably lower due to the smaller share of maize meal in feed compared to that in studies published by other authors (60\%), e.g. Watkins et al. (2001). The sum of SFA decreased with the increase in the share of rye in feed and this amounted to $35.4 \%$, $33.2 \%$ or $31.2 \%$, respectively, in Groups I, II or III. For comparison, the sum of SFA in Watkins et al. (2001) was 35.9\%. A large amount of palmitic acid introduced with animal raw materials to the human diet may lead to a significant increase in triglycerides, LDL cholesterol and a slight increase in the HDL fraction, although it should be remembered that the proportion of SFA in egg yolks is balanced by a large amount of unsaturated acids (Siepka et al., 2015). According to literature data, stearic acid has no effect on the cholesterol metabolism in the human body (Siepka et al., 2015). When analysing the results of the analysis of unsaturated fatty acids in yolks, the sum of MUFA (51.0-56.4\%) recorded in the present study was in accordance with literature data (Grobas et al., 2001) concerning eggs obtained from hens fed with a commercial mixture $(51.9 \%)$. The increase in the sum of MUFA coincided with the increase in the share of rye in the forage fodder. The differences obtained in this study are more significant than in the case of enrichment with rape. The above authors enriched fodder with rape but observed a slight increase in MUFA and a small decrease in SFA. PUFAs are very important from a nutritional point of view. From $\alpha$-linolenic acids C18:3n-3 (ALA) and linoleic C18:2n-6 (LA), as a result of carbon chain elongation, are obtained acids important in maintaining the integrity of cell membranes, the initiation of pro- or anti-inflammatory reactions, among others eicosapentaenoic C20:5n-3 (EPA), docosahexaenoic C22:6n-3 (DHA), $\gamma$-linolenic C18:3n-6 (GLA), dihomo- $\gamma$-linolenic C20:3n-6 (DGLA) and arachidonic C20:4n-6 (AA). In the $\omega-3$ fatty acid group, along with the increase in rye content in the feed, a significant increase in $\alpha$-linolenic acid content and docosahexaenoic was observed, along with a beneficial change in the $\omega-6$ fatty acid group, in which a significant reduction in linoleic acid and $\gamma$-linolenic content as well as a statistically insignificant reduction in arachidonic acid were found. The reduction of the sum of $\omega-6$ acids positively influenced the $\omega-6: \omega-3$ ratio. MUFA and PUFA can be included in one of the necessary components of the daily human diet, but their effectiveness depends on the $\omega-6: \omega-3$ ratio and the state of human health. The parent fatty acids of the $\omega-3$ (ALA) and $\omega-6$ (LA) family are not synthesised in the human body and most animals due to the lack of desaturase inserting a double bond in the acid molecule at carbon 
3 and 6, counting from the methyl group; therefore, they must be delivered with food. According to Surai and Sparks (2001) and Samman et al. (2009), the chicken egg is an excellent source of $\omega-6$ acids, mainly linoleic acid, but its content in yolks (on average 9.9-11.3\%), similar to $\omega-3$ acids, depends on the laying hen's diet. In experimental Groups II and III, the share of rapeseed oil was increased, which could be an important source of $\omega-3$ acids. In the nutritional tables of European Union countries, the ALA content in hen eggs ranges from $0.02 \mathrm{~g}$ (France) to $0.27 \mathrm{~g}$ (Germany), LA from $0.89 \mathrm{~g}$ (Finland) to $1.5 \mathrm{~g}$ (Belgium), EPA $46 \mathrm{mg}$ (Denmark) and DHA from $107 \mathrm{mg}$ (Finland) to $180 \mathrm{mg}$ (Denmark). Polish tables for the composition and nutritional values of food determine LA content at $0.70 \mathrm{~g}$, ALA at $0.01 \mathrm{~g}$ and DHA 0.08 g (Kubiski, 2012). Moreover, the results of the microbiological analysis of the egg content did not reveal any growth of mesophilic microorganisms or bacteria in any of the experimental groups that could threaten the safety of the raw material, which indicates the hygiene of laying hens and egg resistance to microbial infections during formation in the fallopian tube, laying and storage.

In conclusion, the rye can be used up to the level of $25 \%$ in laying hen diets without any deleterious effect on any of the examined egg quality parameters in comparison with the control group. The exception was the yolk colour where lower redness, yellowness and higher lightness were found in the rye-receiving groups. Moreover, the incorporation of rye into diets resulted in a beneficial, nutritional effect for consumer health by changes in fatty acid profiles such as lowering the SFA proportions and increasing the proportions of MUFA and PUFA as well as lowering the $\omega-6: \omega-3$ FA ratio as rye levels in the diet increase.

\section{Acknowledgments}

This study was supported by the "ENERGYFEED" grant, contract number BIOSTRATEG/297910/12/NCBR/2016, financed by the National Centre for Research and Development, Poland as well as DS-3705/1/KPPZ/2018.

\section{References}

Bederska-Łojewska D., Świątkiewicz S., Arczewska-Włosek A., Schwarz T. (2017). Rye non-starch polysaccharides: their impact on poultry intestinal physiology, nutrients digestibility and performance indices - a review. Ann. Anim. Sci., 17: 351-369.

Bederska-Łojewska D., Arczewska-Włosek A., Świątkiewicz S., Orczewska-Dudek S., Schwarz T., Puchała M., Krawczyk J., Boros D., Fraś A., Mi c e k P., R a j t a r P. (2019). The effect of different dietary levels of hybrid rye and xylanase addition on the performance and egg quality in laying hens. Brit. Poultry Sci., 60: 423-430.

B i e s i a d a - D r z a z g a B., J a n o c h a A. (2009). Impact of hen breed and rearing system on the quality of eggs for consumption (in Polish). Food. Science. Technology. Quality, 3: 67-74.

B jörk I., Östman E., Kristensen M., A n s on M.N., Pric e R.K., Haenen G.R.M.M., H a venaar M., Knudsen K.E.B., Frid A., Mykkänen H., Welch R.W., Riccardi G. (2012). Cereal grains for nutrition and health benefits: Overview of results from in vitro, animal and human studies in the HEALTHGRAIN project. Trends Food Sci. Technol., 25: 87-100.

B or oś D., Fr ás A. (2015). Monographs and dissertations 49/2015. Plant Breeding and Acclimatization Institute - National Research Institute. 
Calik J. (2011). Assessing the quality of eggs produced by six breeds of egg-laying hens in relation to their age (in Polish). Food. Science. Technology. Quality, 5: 85-93.

Calik J. (2016). The content of selected chemical components in hen eggs depending on egg production cycle (in Polish). Food. Science. Technology. Quality, 3: 54-63.

Cieślik E., G ębusia A. (2011). Functional foods with fructans added (in Polish). Food. Science. Technology. Quality, 2: 27-37.

Dvorak P., Strakova E., Kunowa J. (2007). Egg yolk colour depends upon the composition of feeding mixture for laying hens. Acta Vet. Brno, 76: 121-127.

F ol ch J., Le es M., S l o a n e S tan ley G.H.J. (1957). A simple method for the isolation and purification of total lipids from animal tissues. J. Biol. Chem., 226: 497-509.

Ga lobart J., S a la R., R in c on - C a r ru yo X., M a n zanilla E.G., Vila B., G a s a J. (2004). Egg yolk color as affected by saponification of different natural pigmenting sources. Poultry Sci., 13: $328-334$.

Gani A., Wan i S.M., Ma s o od i F.A., Ha me ed G. (2012). Whole-grain cereal bioactive compounds and their health benefits: A review. J. Food. Proces. Technol., 3: 146.

Grobas S., Méndez J., Lá zaro R., D e B la s C., Mate os G.G. (2001). Influence of source and percentage of fat added to diet on performance and fatty acid composition of egg yolks of two strains of laying hens. Poultry Sci., 80: 1171-1179.

J a n s s e n W.M.M.A. (1989). European table of energy values for poultry feedstuffs. 3rd ed. Beekbergen, Netherlands, Spelderholt Center for Poultry Research and Information Services.

Jasińska I., Kołodziejczyk P., Michniewicz J. (2006). Rye seed as a potential source of pro-health compounds in diet (in Polish). Food. Science. Technology. Quality, 2, Supl.: 85-92.

Kowieska A., Lubowicki R., Jaskowska I. (2011). Chemical composition and nutritional characteristics of several cereal grain (in Polish). Acta Sci. Pol., Zootech., 10: 37-50.

Krawczyk J. (2016). Variation in productive and reproductive traits, and egg quality some lines of laying hens (in Polish). Wiad. Zoot., 54: 130-139.

K u b is ki T. (2012). Production of chicken eggs enriched with essential fatty acids (in Polish). Vet. Life., 87: 386-389.

Lázaro R., García M., A raníbar M.J., Mateo s G.G. (2003). Effect of enzyme addition to wheat-, barley- and rye-based diets on nutrient digestibility and performance of laying hens. Brit. Poultry Sci., 44: 256-265.

Lew ko L., Gornow i c z E. (2016). Quality of chicken eggs in relation to their weight category (in Polish). Pol. Soc. Anim. Prod., 4: 85-94.

L u m p kins B., B at a 1 A. (2005). The bioavailability of lysine and phosphorus in distillers dried grains with solubles. Poultry Sci., 84: 581-586.

L u m p kin s B., B a t a 1 A., D a le N. (2005). Use of distillers dried grains plus solubles in laying hen diets. J. Appl. Poultry Res., 14: 25-31.

P a n C.F., I g bas an F.A., Gu en ter W., M a rquardt R.R. (1998). The effects of enzyme and inorganic phosphorus supplements in wheat and rye based diets on laying hen performance, energy, and phosphorus availability. Poultry Sci., 77: 83-89.

Polish Standard PN-75-A-04018/Az3:2002. Agri-food products. Determination of nitrogen content by the Kjeldahl method and the conversion of protein (in Polish).

Polish Standard PN-A-82112:1973/Az1:2002. Meat and meat products. Determination of chloride content (in Polish).

Polish Standard PN-A-86503:1998 Poultry products. Food eggs (in Polish).

Polish Standard PN-ISO 1442:2000. Meat and meat products. Determination of moisture content (Reference method) (in Polish).

Polish Standard PN-ISO 1444:2000. Meat and meat products. Determination of free fat content (in Polish).

Rus s o M.V., De Le on ardis A., Macciola V. (2005). Solid phase extraction - Gas-chromatographic method to determine free cholesterol in animal fats. J. Food Comp. Anal., 18: 617-624.

S a m man S., Piu Kung F., Carter L.M., Foster M.J., Ahmad Z.I., Phuyal J.L., P et o c z P. (2009). Fatty acid composition of certified organic, conventional and omega-3 eggs. Food Chem., 166: 911-914.

Schwarz T., Kuleta W., Turek A., Tuz R., Nowicki J., Rudzki B., Bartlewski P.M. 
(2015). Assessing the efficiency of using a modern hybrid rye cultivar for pig fattening, with emphasis on production costs and carcass quality. Anim. Prod. Sci., 55: 467-473.

S i e p k a E., B ob a k Ł., G ła d k ow sk i W. (2015). Characteristics of biological activity of phospholipids in egg yolk (in Polish). Food. Science. Technology. Quality, 2: 15-28.

S mulikowska S., Swiech E., Mieczkowska A. (1997). The effect of feeding whole wheat or rye and enzyme supplementation on laying performance, gizzard size and viscosity of intestinal digesta in hens J. Anim. Feed Sci., 6: 541-547.

S m u lik ow sk a S., R u tk ow sk i A. (2005). Standards of Poultry Nutrition. 4th ed., supplemented. The Kielanowski Institute of Animal Physiology and Nutrition PAN.

Sokołowicz Z., Krawczyk J., Herbut E. (2012). Quality of eggs from organically reared laying hens during their first and second year of production (in Polish). Food. Science. Technology. Quality, 4: 185-194.

S u r a i P.F., S p ark s N.H.C. (2001). Designer eggs: from improvement of egg composition to functional food. Trends Food Sci. Technol., 12: 7-16.

Św iątki ew ic z S., Koreleski J. (2007). Effect of dietary level of maize and rye distiller dried grains with solubles on nutrient utilization and digesta viscosity in laying hens. J. Anim. Feed Sci., 16: 668-677.

W a t k in s B.A., D e vit t A.A., F e ng S. (2001). Designed eggs containing conjugated linoleic acids and omega-3 polyunsaturated fatty acids. World Rev. Nutr. Diet., 90: 162-182.

Wy s ze c k i G., S ti l e s W.S. (1982). Colour Science: Concepts and Methods, Quantitative Data and Formulae. New York, USA, John Wiley, 2nd ed.

Received: 13 I 2019

Accepted: 29 III 2019 